\title{
Expression and localization of aromatase during fetal mouse testis development
}

\author{
Caroline Borday ${ }^{1,2,3+}$, Jorge Merlet ${ }^{1,2,3+}$, Chrystèle Racine ${ }^{1,2,3}$ and René Habert ${ }^{1,2,3^{*}}$
}

\begin{abstract}
Background: Both androgens and estrogens are necessary to ensure proper testis development and function. Studies on endocrine disruptors have highlighted the importance of maintaining the balance between androgens and estrogens during fetal development, when testis is highly sensitive to environmental disturbances. This balance is regulated mainly through an enzymatic cascade that converts irreversibly androgens into estrogens. The most important and regulated component of this cascade is its terminal enzyme: the cytochrome p450 19A1 (aromatase hereafter). This study was conducted to improve our knowledge about its expression during mouse testis development.

Findings: By RT-PCR and western blotting, we show that full-length aromatase is expressed as early as 12.5 day post-coitum (dpc) with maximal expression at $17.5 \mathrm{dpc}$. Two additional truncated transcripts were also detected by RT-PCR. Immunostaining of fetal testis sections and of gonocyte-enriched cell cultures revealed that aromatase is strongly expressed in fetal Leydig cells and at variable levels in gonocytes. Conversely, it was not detected in Sertoli cells.

Conclusions: This study shows for the first time that i) aromatase is expressed from the early stages of fetal testis development, ii) it is expressed in mouse gonocytes suggesting that fetal germ cells exert an endocrine function in this species and that the ratio between estrogens and androgens may be higher inside gonocytes than in the interstitial fluid. Furthermore, we emphasized a species-specific cell localization. Indeed, previous works found that in the rat aromatase is expressed both in Sertoli and Leydig cells. We propose to take into account this species difference as a new concept to better understand the changes in susceptibility to Endocrine Disruptors from one species to another.
\end{abstract}

Keywords: Cyp19a1, Aromatase, Testis, Fetus, Mouse, Gonocytes, Development, Endocrine disruptors, Leydig cells, Souris, Développement, Perturbateurs endocriniens, Cellules de Leydig

\section{Résumé}

Les androgènes et les oestrogènes sont indispensables au développement et aux fonctions du testicule. Le testicule est particulièrement sensible aux perturbateurs endocriniens pendant le développement fœtal et beaucoup de perturbateurs endocriniens agissent en modifiant la balance oestrogènes/androgènes. Physiologiquement, cette balance est régulée par une cascade enzymatique qui convertit irréversiblement les androgènes en oestrogènes. Le composant principal de cette cascade est le cytochrome p450 19A1 (appelé couramment aromatase). Le but de ce travail a été d'étudier l'expression de l'aromatase testiculaire au cours du développement fotal chez la souris. (Continued on next page)

\footnotetext{
* Correspondence: rene.habert@cea.fr

${ }^{\dagger}$ Equal contributors

'Laboratory of Development of the Gonads, Unit of Stem Cells and

Radiation, Univ. Paris Diderot, Sorbonne Paris Cité, BP 6,

92265 Fontenay-aux-Roses, France

${ }^{2}$ CEA, DSV, iRCM, SCSR, LDG,

92265 Fontenay-aux-Roses, France

Full list of author information is available at the end of the article
}

() Biomed Central

(c) 2013 Borday et al.; licensee BioMed Central Ltd. This is an Open Access article distributed under the terms of the Creative Commons Attribution License (http://creativecommons.org/licenses/by/2.0), which permits unrestricted use, distribution, and reproduction in any medium, provided the original work is properly cited. 
(Continued from previous page)

En utilisant une approche par RT-PCR et par western blot, nous avons montré que l'aromatase est exprimée dès 12,5 jours post-conception (jpc) et que l'expression est maximum à 17,5 jpc. Deux transcripts tronqués ont également été détectés par RT-PCR. La localisation cellulaire de l'aromatase a été étudiée par immunohistologie et par immunomarquage après séparation des cellules testiculaires. Cette enzyme est très fortement exprimée dans les cellules de Leydig fœtales. Elle est également exprimée dans les gonocytes mais plus faiblement et à un niveau variable selon les cellules. En revanche, elle est indétectable dans les cellules de Sertoli.

En conclusion, cette étude montre pour la première fois chez la souris que 1) l'aromatase est exprimée dès le début de l'ontogenèse testiculaire, 2) elle est exprimée dans les gonocytes suggérant que ces cellules interviennent dans l'endocrinologie testiculaire et que le rapport oestrogènes/androgènes est plus important dans les gonocytes que dans le liquide interstitiel. En outre, on sait que, chez le fœetus de rat l'aromatase est essentiellement exprimée par les cellules de Sertoli. Nous proposons de prendre en compte cette différence inter-espèces comme un nouveau concept pour comprendre les différences de sensibilité aux perturbateurs endocriniens d'une espèce à l'autre.

Mots-clés: Cyp19a1, Aromatase, Testis, Foetus, Souris, Gonocytes, Développement, Perturbateurs endocriniens, Cellules de Leydig

\section{Findings}

Ontogenesis of cytochrome P450 aromatase expression in the mouse testis during fetal development

C57BL/6 mice bred in our animal facility were housed under controlled photoperiod conditions (lights from 08:00 to 20:00 h) with commercial food and tap water supplied ad libitum, as previously described $[1,2]$. The day after overnight mating was counted as 0.5 day post-coitum $(\mathrm{dpc})$. The animal facility is licensed by the French Ministry of Agriculture (agreement $\left.\mathrm{N}^{\circ} \mathrm{B} 92-032-02\right)$. All animal experiments were supervised by Pr. René Habert (agreement delivered by the French Ministry of Agriculture for animal experimentation $\mathrm{N}^{\circ}$ 92-191) in compliance with the NIH Guide for Care and Use of Laboratory Animals.

In this paper, we focussed on the ontogenesis of cytochrome P450 aromatase (accession \# NP_031836 for protein and NM_007810.3 for mRNA), and named "aromatase" thereafter. To characterize aromatase expression during mouse testis development, its mRNA level was analyzed by RT-PCR from $12.5 \mathrm{dpc}$ to birth. Three transcript variants, called T1, T2 and T3, were detected (Figure 1A-B). T1 and T2 were observed as early as $12.5 \mathrm{dpc}$. Sequencing confirmed that they were bona fide aromatase variants and showed that they corresponded to full-length aromatase (T1) and to the splicing variants without exon 3 (T2) and without exons 3 and 4 (T3) (see Additional file 1).

In order to quantify these variants during embryogenesis, we performed quantitative real-time RT-PCR (qRT-PCR) using the TaqMan method which allows the detection of each isoform using three different internal probes each one specific for one isoform (Figure 1A and Table 1 for sequences and conditions). We showed that $\mathrm{T} 1$ and $\mathrm{T} 2$ expression in the testis increased by around 20-fold between 13.5 and $17.5 \mathrm{dpc}$ and thereafter started to progressively decrease (Figure $1 \mathrm{C}$ ).
To determine if aromatase is translated in mouse testis, western blot analysis was performed using a specific anti-aromatase antibody (MCA2077T, Serotec, France) (Figure 1D). Two proteins around $54 \mathrm{kDa}$ and one around $27 \mathrm{kDa}$ were detected. The protein of $54 \mathrm{kDa}$ was also present in the ovary extract and it approximately corresponds to the aromatase expected size. We thus suppose that the two heaviest proteins derived from the full-length form of aromatase (T1) with the highest form corresponding to a testis-specific post-translational modification that remains to be identified. In order to understand the origin of the $27 \mathrm{kDa}$ protein, we analysed sequences of the T2 and T3 variants. It revealed that the splicing of exon 3 in T2 would change the ORF and create a precocious codon stop leading to a probably not detected protein of $6 \mathrm{kDa}$. Splicing of exons 3 and 4 in T3 would not change the ORF allowing in theory the synthesis of a truncated protein of $46 \mathrm{kDa}$. No protein at this expected size was detected in the western blot (Figure 1D). However, the use of an alternative start codon located later in $\mathrm{T} 2$ and $\mathrm{T} 3$ sequences may lead to a protein of $27 \mathrm{kDa}$ containing the C-terminal part of aromatase.

These findings are different from those of the only previously published paper on this topic showing that, in the mouse, aromatase expression starts at $17.5 \mathrm{dpc}$ and reaches the highest level at day 1 post-partum [3]. In our study, we detected aromatase expression as early as 12.5 dpc. This discrepancy probably results from the improvement of the methods of detection made since 1994. This is an important point because it shows that estrogens can be produced by mouse fetal testes very early and throughout development.

Our findings indicate that different aromatase transcripts are generated in fetal mouse testes. Previous studies in different mammalian species (including the mouse) reported 
A

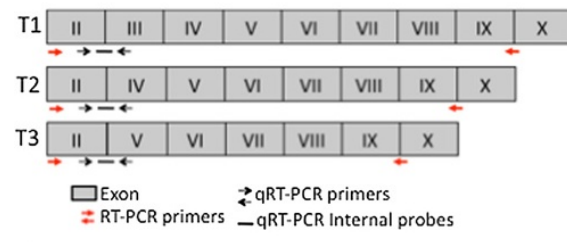

C

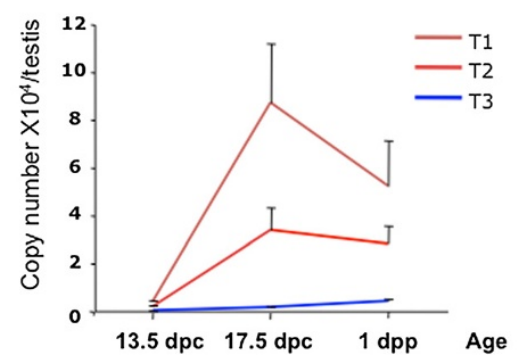

B

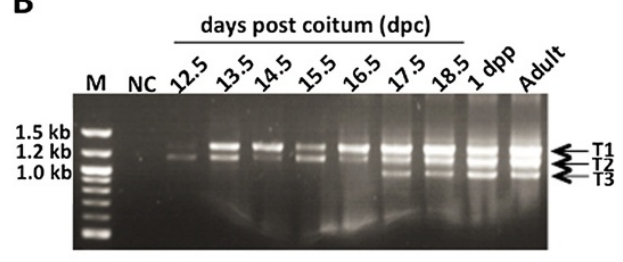

D

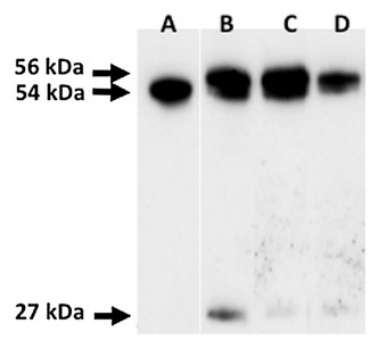

Figure 1 Aromatase expression in mouse fetal testis. A. Scheme showing the different testis aromatase variants (T1, T2 and T3). Aromatase exons from exon 2 to exon 10 are represented (gray boxes) for each transcript variant T1, T2 and T3. For each variant the relative position of the RT-PCR primers (red arrows), quantitative qRT-PCR (black arrows) and internal probes (blacks lines) used are represented. B. Expression of different aromatase transcript variants (T1, T2 and T3) during mouse testis development. Products were generated by RT-PCR with the primer combinations E2-E9/10 (see Table 1) and visualized on 2\% agarose gel. NC: 3 negative control (PCR master mix without template). M: DNA ladder; dpc: days post-coitum; dpp: days post-partum. C. Absolute quantitative expression of aromatase transcripts during mouse testis development. Total mRNA was isolated from fetal testes at the indicated stages of development, reverse transcribed and aromatase expression was quantified by real-time PCR using the TaqMan method. This method allows the identification of each isoform by using a specific internal probe (see Figure 1A for position and Table 1 for sequences). In order to calculate precisely the copy number of each transcript, each transcript was isolated on gel, re-amplified and quantified. For each experiment a standard curve was constructed using the isolated transcript as template with their corresponding qRT-PCR primers. Data shown are the mean \pm SEM $(n=4-6)$. ${ }^{*} P<0.05$ (Student's $t$-test; compared to the mRNA copy number at $13.5 \mathrm{dpc}$ ). D. Aromatase protein expression during mouse testis development. On western blots, three protein isoforms were recognized by the anti-aromatase antibody (MCA2077T, Serotec, France). Lane A, ovary from a pregnant mouse: only one band that corresponds to the aromatase full-length protein. Lane B, 2 dpp mouse testis; lane C and D, extracts from 15.5 and $13.5 \mathrm{dpc}$ mouse testes, respectively.

Table 1 Sequences of aromatase primers used in RT-PCR and qRT-PCR

\begin{tabular}{lccc}
\hline & & Sequence 5'-3' & Tm \\
\hline RT-PCR all & forward & AACCCCATGCAGTATAATGTC & $55^{\circ} \mathrm{C}$ \\
transcripts & reverse & CATTCTTCTCAAAGTTTCA & \\
T1 qRT-PCR & forward & GCCTCCTTCTCCTGATTTGGA & $60^{\circ} \mathrm{C}$ \\
& reverse & CTGCCATGGGAAATGAGGG & \\
& internal probe & TACCAGGTCCTGGCTACT & \\
T2 qRT-PCR & forward & GCCTCCTTCTCCTGAATTGGA & $60^{\circ} \mathrm{C}$ \\
& reverse & CCGAATCGGGAGATGTAGTGA & \\
& internal probe & TCAATACCAGGTCCTCAAGC & \\
T3 qRT-PCR & forward & CCATGCCACTCCTGCTGAT & $60^{\circ} \mathrm{C}$ \\
& reverse & CCACCATTCGAACAAGACCAG & \\
& internal probe & TCTCAATACCAGCTCTGACGGGCC & \\
\hline
\end{tabular}

that tissue-specific aromatase expression is driven by specific promoters [4-6]. Each tissue-specific promoter is associated with a specific untranslated first exon. In mice testis Golovine et al. have shown that aromatase transcripts may emerge from a specific promoter called Ptes [4]. Our study showed that aromatase expression is also regulated at a second transcriptional level generating two additional truncated variants T2 and T3 by mRNA splicing. Our results suggest that there are several forms of aromatase protein however the nature and the physiological function of these isoforms remain to be investigated.

\section{Aromatase cell localization in mouse fetal testes}

Immunohistochemical analysis of aromatase localization in $17.5 \mathrm{dpc}$ mouse testes using a specific anti-aromatase antibody (MCA2077T, Serotec, France) showed a strong staining in Leydig cells. Importantly, there was no detectable staining in Sertoli cells (Figure 2A). Conversely, previous studies in fetal and neonatal testes showed that aromatase was expressed in both Leydig cells and Sertoli cells in the rat $[7,8]$. This and other previous reports indicate that aromatase cell localization in fetal testis is quite variable in mammalian species. Indeed, aromatase is 


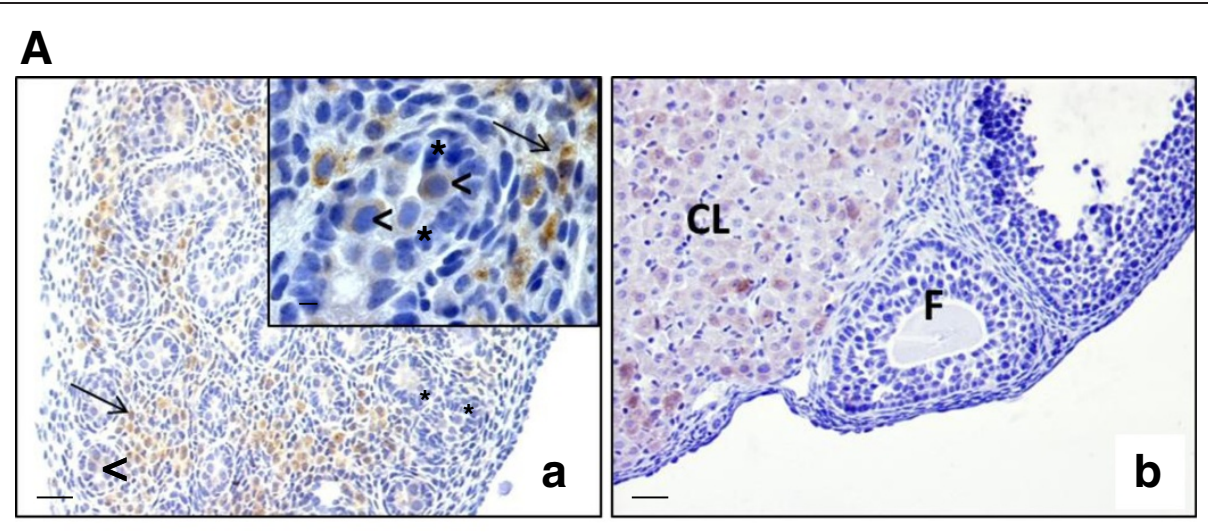

B

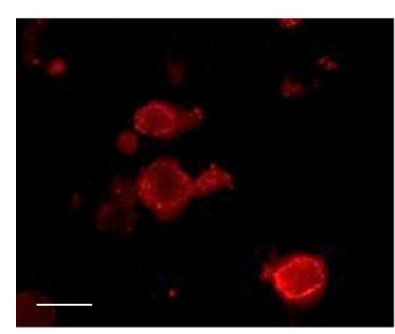

VASA

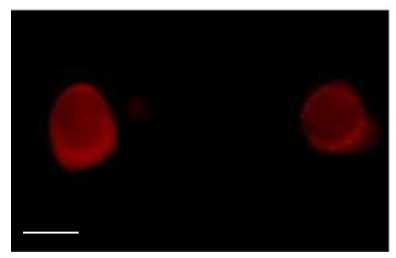

Aromatase

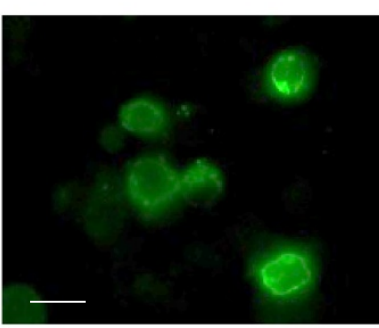

Aromatase

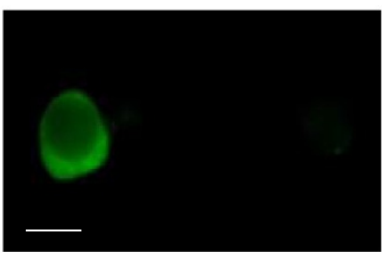

Merge

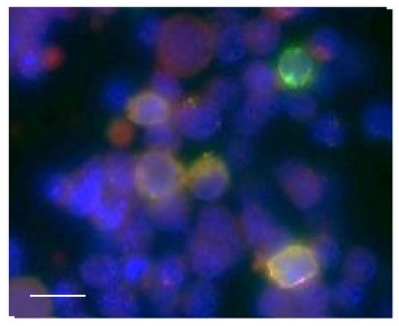

Merge

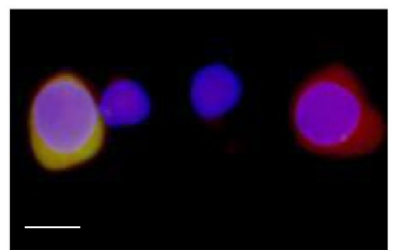

Figure 2 Aromatase cell localization in mouse fetal testis. A. Aromatase immunodetection in $17.5 \mathrm{dpc}$ testes. Immunostaining was performed using an anti-aromatase antibody (MCA2077T, Serotec, France), followed by a biotin-conjugated secondary antibody and streptavidinperoxidase visualization with DAB (Vector Laboratories). (a) A strong specific immunoreactivity was observed in Leydig cells within the interstitial tissue (arrows) and to a lesser extent in gonocytes (arrowheads). Inset is a higher magnification to show that aromatase is localized only in the cytoplasm of Leydig cells (arrows) and gonocytes (arrowheads) and is absent or not detectable in the Sertoli cells (asterisks). (b) Control section (ovary from adult pregnant rat): positive staining is observed in the corpora lutea (CL) but not in the pre-antral follicle (F), as previously described [13]. Scale bars $=5 \mu \mathrm{m}$. B. Double immunofluorescence staining for aromatase, 3ßHSD (Leydig cell marker) and VASA (germ cell marker) in enriched gonocyte cultures. Immunostaining was performed using anti-aromatase (MCA2077T, Serotec, France) (green), anti-3 3 HSD (generous gift by J.I Mason) (red) and anti-VASA antibodies (ab13840, Abcam, France) (red). Aromatase expression was detected both in 3ßHSD-positive cells and in VASA-positive cells. Nuclei were visualized with 4'-6 diaminido-2-phenylindole (DAPI) (blue). Scale bars $=10 \mu \mathrm{m}$.

expressed in Leydig cells and not in Sertoli cells in the fetal testis of the Plains Vizcacha rodent [9], is totally absent in the deer [10], and is detected in both Sertoli cells and Leydig cells in fetal baboon and human testes [11,12].

In addition, our immunohistochemical analysis showed that aromatase was also expressed in gonocytes, but the intensity of the signal was not uniform: in some cells the signal was very strong, whereas in others it was faint or undetectable (Figure 2A, arrowheads). Similar results were previously described for Retinoic Acid Receptor alpha [14]. As aromatase localization in germ cells was quite unexpected, aromatase immunostaining was also performed in enriched gonocyte cultures that were prepared from $17.5 \mathrm{dpc}$ mouse testes as previously described [15]. Similarly, aromatase was detected in some germ cell VASA-positive cells, a germ cell-specific marker (Figure 2B). This result identifies a sub-population of gonocytes with endocrine function. Aromatase expression was previously reported in adult rat and human germ cells $[16,17]$ and in pig gonocytes during development [18]. Aromatase expression was also detected in gonocytes of human fetal testes [12].

In conclusion, aromatase cell localization in fetal testis appears to differ from one species to another and as 
consequence also the intracellular estrogen concentration. These differences should be taken into account to explain the variations in the susceptibility of fetal testis to estrogenic and anti-androgenic endocrine disruptors in different mammalian species that has been recently lightened [2].

\section{Additional file}

Additional file 1: Sequencing results of T1, T2 and T3. The three different transcripts were isolated on gel and sequenced with the following primers: forward 5'-AACCCCATGCAGTATAATGTC-3' (located in exon II); reverse 5'-CACAATAGCACTITCGTCCA-3' (located in exon V). Each different exon is highlighted in a different color (red exon II, black exon III, and blue exon IV and green exon V. In addition, sequencing from exons $\mathrm{VI}$ to $\mathrm{X}$ were performed using other primers and showed no difference in T1, T2 and T3 (data not shown).

\section{Competing interests}

All authors declare that they have no competing interests.

\section{Authors' contributions}

Conceived the study: $\mathrm{RH}$. Conceived and designed the experiments: $\mathrm{RH}, \mathrm{CR}$. Performed the experiments: $C B, J M, C R$. Analyzed the data: $C B, J M, R H, C R$. Contributed reagents, materials, analysis tools and financial supports: $\mathrm{RH}$. Wrote the paper: $\mathrm{RH}, \mathrm{CR}$. Improved the redaction: $\mathrm{CB}, \mathrm{JM}$. All authors read and approved the final manuscript.

\section{Acknowledgements}

We thank Véronique Neuville for animal care, Evelyne Moreau and Sebastien Messiaen for technical assistance, Aurélie Gouret for secretarial help and E. Andermarcher for editing the English manuscript.

\section{Funding}

This work was supported by Université Paris Diderot-Paris 7, CEA and INSERM. J.M. was supported by a fellowship from the Ministère de I'Education Nationale de la Recherche et de la Technologie. CB holds a position as Temporary Attached for Teaching and Research (ATER) at the Diderot-Paris 7 University.

\section{Author details}

${ }^{1}$ Laboratory of Development of the Gonads, Unit of Stem Cells and Radiation, Univ. Paris Diderot, Sorbonne Paris Cité, BP 6 ,

92265 Fontenay-aux-Roses, France. ${ }^{2}$ CEA, DSV, iRCM, SCSR, LDG,

92265 Fontenay-aux-Roses, France. ${ }^{3}$ Unit of Stem Cells and Radiation, LDG / SCSR / iRCM / DSV, INSERM, Centre CEA, BP6, Unité 967, F-92265 Fontenay aux Roses, France.

Received: 9 June 2013 Accepted: 9 September 2013

Published:1December 2013

\section{References}

1. Merlet J, Moreau E, Habert R, Racine C: Development of fetal testicular cells in androgen receptor deficient mice. Cell Cycle 2007, 6:2258-2262.

2. NTumba-Byn T, Moison D, Lacroix M, Lecureuil C, Lesage L, Prud'homme SM, Pozzi-Gaudin S, Frydman R, Benachi A, Livera G, Rouiller-Fabre V, Habert R: Differential effects of bisphenol $A$ and diethylstilbestrol on human, rat and mouse fetal Leydig cell function. PLoS One 2012, 7:e53257.

3. Greco TL, Payne AH: Ontogeny of expression of the genes for steroidogenic enzymes P450 side-chain cleavage, 3beta-hydroxysteroid dehydrogenase, P450 17alpha-hydroxylase/C17-20 lyase, and P450 aromatase in fetal mouse gonads. Endocrinology 1994, 135:262-268.

4. Golovine K, Schwerin M, Vanselow J: Three different promoters control expression of the aromatase cytochrome p450 gene (cyp19) in mouse gonads and brain. Biol Reprod 2003, 68:978-984.

5. Chow JD, Simpson ER, Boon WC: Alternative 5'-untranslated first exons of the mouse Cyp19A1 (aromatase) gene. J Steroid Biochem Mol Biol 2009, 115:115-125.
6. Von Schalburg KR, Yasuike M, Davidson WS, Koop BF: Regulation, expression and characterization of aromatase (cyp19b1) transcripts in ovary and testis of rainbow trout (Oncorhynchus mykiss). Comp Biochem Physiol B Biochem Mol Biol 2010, 155:118-125.

7. Tsai-Morris $\mathrm{CH}$, Aquilano DR, Dufau ML: Cellular localization of rat testicular aromatase activity during development. Endocrinology 1985, 116:38-46

8. Rouiller-Fabre V, Carmona S, Merhi RA, Cate R, Habert R, Vigier B: Effect of anti-Mullerian hormone on Sertoli and Leydig cell functions in fetal and immature rats. Endocrinology 1998, 139:1213-1220.

9. Gonzales CR, Muscarsel Isla ML, Leopardo NP, Willis MA, Dorfman VB, Vitullo $A D$ : Expression of androgen receptor, estrogen receptors alpha and beta and aromatase in the fetal, perinatal, prepubertal and adult testes of the South American plains Vizcacha, Lagostomus maximus (Mammalia, Rodentia). J Reprod Dev 2012, 58:669-35.

10. Hayakawa D, Sasaki M, Suzuki M, Tsubota T, Igota H, Kaji K, Kitamura N: Immunohistochemical localization of steroidogenic enzymes in the testis of the Sika Deer (Cervus nippon) during developmental and seasonal changes. J Reprod Dev 2010, 56:117-123.

11. Bonagura TW, Zhou H, Babischkin JS, Pepe GJ, Albrecht ED: Expression of P-450 aromatase, estrogen receptor $a$ and $\beta$, and $\alpha$-inhibin in the fetal baboon testis after estrogen suppression during the second half of gestation. Endocrine 2011, 39:75-82.

12. Boukari K, Ciampi ML, Guiochon-Mantel A, Young J, Lombès M, Meduri G: Human fetal testis: source of estrogen and target of estrogen action. Hum Reprod 2007, 22:1885-1892.

13. Turner KJ, Macpherson S, Millar MR, McNeilly AS, Williams K, Cranfield M, Groome NP, Sharpe RM, Fraser HM, Saunders PT: Development and validation of a new monoclonal antibody to mammalian aromatase. J Endocrinol 2002, 172:21-30.

14. Boulogne B, Levacher C, Durand P, Habert R: Retinoic acid receptors and retinoid $X$ receptors in the rat testis during fetal and postnatal development: immunolocalization and implication in the control of the number of gonocytes. Biol Reprod 1999, 61:1548-1557.

15. Merlet J, Racine C, Moreau E, Moreno SG, Habert R: Male fetal germ cells are targets for androgens that physiologically inhibit their proliferation. Proc Natl Acad Sci USA 2007, 104:3615-3620.

16. Lambard S, Silandre D, Delalande C, Denis-Galeraud I, Bourguiba S, Carreau S: Aromatase in testis: expression and role in male reproduction. J Steroid Biochem Mol Biol 2005, 95:63-66.

17. Carreau S, Bois C, Zanatta L, Silva FR, Bouraima-Lelong H, Delalande C: Estrogen signaling in testicular cells. Life Sci 2011, 89:584-587.

18. Haeussler S, Wagner A, Welter H, Claus R: Changes of testicular aromatase expression during fetal development in male pigs (Susscrofa). Reproduction 2007, 133:323-330.

doi:10.1186/2051-4190-23-12

Cite this article as: Borday et al:: Expression and localization of aromatase during fetal mouse testis development. Basic and Clinical Andrology 2013 23:12.

\section{Submit your next manuscript to BioMed Central and take full advantage of:}

- Convenient online submission

- Thorough peer review

- No space constraints or color figure charges

- Immediate publication on acceptance

- Inclusion in PubMed, CAS, Scopus and Google Scholar

- Research which is freely available for redistribution 